monetary or fiscal measures. (2) The changes in supply and demand that are part of a progressive economy may impart an upward bias to the price-level. (3) Differences in the rate of growth of productivity between industries may also impart an upward bias.

It will be impossible to escape these tendencies while there is excess demand for goods or for labour, and the prospect of price stability and of long-run growth would be improved by running the economy a little less near to the absolute limit of capacity than it has been in recent years. Other necessary conditions for the avoidance of inflation are the breaking down of expectations that higher wages costs can be automatically passed on in higher prices; and the use of a greater part of the gains from increased productivity to reduce prices rather than to raise wages or profits. Discussions between Government, employers' organizations and Unions can help in establishing these conditions, though it is necessary to guard against dangers of inflexibility which may be implied in an incomes policy.

\title{
MAN'S USE OF NATURAL RESOURCES
}

$\mathrm{P}^{\mathrm{R}}$ ROF. E. M. JOPE, in his presidential address to Section $H$ (Anthropology), points out that some natural resources have, in human hands, held high potential in shaping (or hindering) cultural development. It is man's awareness of his just place in a finely balanced ecology at both subsistence and cultural levels which leads to civilized fulfilment.

Some stages seem to have been particularly crucial in rising humanism. There is the long upsurge of controlled food-production through Asia into Europe and in the New World; there is the rise of metallurgy, particularly of steel, and the steepening rise of power-technology in the West from the Middle Ages onwards; and there is the increasing command over materials which has led to the creative molecular architecture of specifically designed synthetic substances.

The evolution of effective food-production was a long-protracted process, first in western Asia from about 9000 to 5000 B.C., there and in south-east Europe adapted to a particular range of terrains. We should not too readily assume that this pattern of farming was implanted ready-formed into the very different conditions of temperate Europe, to yield the viable food-producing way of life found extending across European temperate forests from the west Balkans to the North Sea coastlands during the fifth millennium B.C.

Early domestication of plants is perhaps a little better understood than that of animals which, in the initial stages, must be seen largely through the archaeological contexts of faunal remains differing little, if at all, from the wild. Biological data can, however, be most revealing of lines of ancestry in domestic stocks, particularly in the ancestral relations to be traced in their multiple protein systems, or even in polysaccharides. Such molecular genetics is of great potential, especially if it could be extended to the insoluble proteins such as keratins or those of bone structure, a residuum of which survives intact in ancient bone; it might also be applied to soft tissues preserved by special conditions, as with the Altai horses. With these insoluble proteins, two-dimensional mapping of the constituent peptides ('finger-printing') is probably necessary.

The use of traction animals, and hence of wheeled transport, is another aspect of controlled animal breeding, and properly designed harnessing of their effort is vital. Here the Chinese, as in many other matters, initiated crucial advances long before they appeared in the West, as with the padded horse-collar, or effective harnessing of wind-power in sailing ships controlled through the stern-post rudder. But it was only through the social urge of the medieval West that these germs were exploited to lead into modern power technology. That England, even in later Saxon times, was well to the forefront of these medieval advances is well shown by recent large-scale excavations, as of the tenth-century water-mill system at Old Windsor.

Two inventions, the fire-piston and the crank, again initiated early in the Far East, were not exploited in combination as a source of powered continuous rotary motion until the great Western developments of steam engines in the nineteenth century and the internalcombustion engines of the twentieth century. In these, especially the former, Britain again led the field. Demand on her excellent coal resources increased all this (the rising province of industrial archaeology), yielding a large chemical industry from its by-product outfall.

The archaeology and social anthropology of food and power resources are of the greatest importance in planning the viable use of the Earth, and the avoidance of manmade desolation, again as much at the level of cultural satisfaction as of subsistence.

Unlike the more dynamic resources, static resources are restricted and not continually regenerated from solar energy or as part of a natural biological cycle. But by expanding the use of varied materials into a profusion of man-made and man-designed substances, man has deployed the resources of Nature into an advantageous ecological pattern. Most important of all was the rise of alloy metallurgy, the interim stage of bronzes, then the carbon- and, from the nineteenth century, the alloysteels. The refined use of materials and of the subtle nuances of their texture for artistic expression must not be overlooked. The ultimate elegance is seen in our full understanding of structure in relation to behaviour in even the most complex molecules of Nature, and the recent development of artificial substances designed with increasing precision for specific purposes (molecular architecture or molecular stmuctural engineering) is one of man's greatest ecological achievements, for he has thereby created renewable cycles from the simplest of raw materials, the atoms themselves. The implications of extending this molecular architecture to full genetic control are serious and must not be ignored. It remains to be seen how these and the further extension into nuclear architecture can influence the nature of human society.

\section{THE ENERGETICS OF RUNNING}

GORTY years ago the subject of Prof. A. V. Hill's presidential address to Section I (Physiology and Biochemistry) was "The Physiological Basis of Athletic Records", and Mr. B. B. Lloyd reverts to Hill's theme in his presidential address this year, applying Hill's arguments and ideas to present-day records in the light of modern views on energy stores and supply rates and on the relation between the power output of a runner and his velocity. 